\section{An Auldregs}

\author{
ON THE
}

\section{WORK OF THE RESEARCH DEFENCE SOCIETY.}

Delivered before the North London Medical and Chirurgical Society.

\section{BY ' STEPHEN , PAGET, F.R.C.S.,} HONORARY SECRETARY OF THE SOCIETY.

IT was a great pleasure to me to be told that I was not free to take what theme I liked, but was bound to speak on that one theme which, if I had been free, I should have chosen. The work of the Research Defence Society has been so full of interest and of happiness, that I found myself, when your kind invitation came, heartily glad that you would let me speak of it this evening.

Many of us remember the first Royal Commission, appointed in 1875 to inquire into experiments on animals. The contrast is very significant, between the evidence given before that Commission and the evidence before the present Royal Commission. Truly, as we turn from the one set of. Blue Books to the other, we seem almost to pass into a new world. In 1875, the evidence was mainly physiological, and even in Physiology there were no such triumphs to be declared as the present Royal Commission has lately heard with its own ears. As for Pathologynext to nothing was said about Pathology; and there was nothing said about Bacteriology-nothing, at any rate, except one or two vague and splendid prophecies, especially that magnificent passage in Sir John Simon's evidence touching the nature of anthrax:

We are going through a progressive work that has many stages, and are now getting more precise knowledge of the contagium. By these experiments on sheep it has been made quite clear that the contagium of sheep-pox is something of which the habits can be studied, as the habits of a fern or moss can be studied: and we look forward to opportumities of thus studying the contagium outside the body which it infects. This is not a thing to be done in a day, or perhaps in ten years, but must extend over a long period of time. Dr. Klein's present paper represents one-very important stage of a vast special study. He gives the identification of the contagium as something which he has studied to the end in the infected body and which can nove in a future stage be studied outside the body.

But of course a Royal Commission cannot live on prophecies. The evidence before the 1875 Commission is, in great part, retrospective and historical. The witnesses proved, past all possibility of doubt, the value and the necessity of experiments on animals, and with that proof the Commissioners were content. They sat for sis months only, they examined fifty-three witnesses and no more, and the total number of questions and answers attains the comparatively moderate figure of 6,551. The Act founded on their recommendations was passed in 1876 .

If prophecy be out of place before a Royal Commission, it is even more out of place in an Act of Parliament. Therefore, ever since 1876, we have seen the Act strained and pulled this way and that, so that it may somehow be applied to the growing needs of science. For example, there is, even now, no special certificate for inoculations; yet inoculations, with a few experiments of the nature of inoculations, are, at the present time, 96.5 per cent. of all experiments on animals. Thus the public are left to believe that severe operations are performed on animals without anaesthesia; and we all know what use is made of this defect in the Act, by the opponents of these experiments.

Of course, the text of an Act of Parliament is nothing more than a skeleton. The life of an Act of Parliament is not in the words of the Act, but in the administration of the Act. All sorts of restrictions and special conditions are enforced by the Home Office, beyond the text of the Act. It is plainly illogical to say that the Act allows this, that, and the other to be done to animals, as if the bare bones of the Act were alive. The Act is the administration of the Act, and this particular Act is administered with most commendable care and inquiry, and with frequent correspondence and consultation. There never was an Act less, capable of administering itself.

In 1882, six years after the passing of the Act, some of the chief members of our profession founded the Association for the Advancement of Medicine by Research; among them were Lord Lister, Sir James Paget, Sir William Gull, Sir William Bowman, Sir Richard Quain, and Sir Andrew Clark. The purpose of this association was "to bring the legitimate influence of the medical profession more effectively to bear on the promotion of those exact researches in physiology, pathology, and therapeutics, which are essential to the sound progress of the healing art." The council of this association made an offer to the Home Office " to render, within their province, such aid or advice, as would tend to facilitate the administrations of the statute, without trenching upon the absolute discretion committed to the Home Secretary." This offer was immediately accepted by Sir :William Harcourt, then Home Secretary; and, in December, 1882 it was decided that no application under the Act should be entertained by the Home Office, except on the recommendation of the council of this association. From that time till now, for more than a quarter of a century, this association has been the constant adviser of the Home Office.

But we need not stay over these old facts of more than thirty years ago. The Act had hardly received the Royal Assent before it began to be ill adapted for its purpose. It becrme law in 1876, and it was in 1878 that Pasteur took part in that memorable discussion, in the French Academy of Medicine, on puerperal fever. The story is worth telling again and again: how, at a solemn meeting, a pathologist of the old school was arguing in a learned way as to the causes of epidemics in lying-in hospitals; and Pasteur, from the place where he was sitting, suddenly interrupted the speaker. "The cause of the epidemic," he cried, "has nothing to do with all that; it is the doctor, and the people round him, who carry the microbe from the patient to the healthy woman." Then the oracular reply came back: "I am atraid that nobody will ever find that microbe.". And then Pasteur walked up to the blackboard, drew on it the streptococcus, and said, "There, that's what it's like."

Henceforward, of course, began the rapid and continual increase of the number of experiments on animals. Many years ago I made a chart, like a temperature chart, of the number of experiments each year in this country. The line rushed up swiftly, and has not yet ceased to rise, though the increase is nothing now, compared to the increase in the years between 1880 and 1890 . Still, if any member of the 1875 Commission were now to see the official returns of experiments made in 1907, he would think that there was material for another Royal Commission. It is not for me to inquire what motives, in ethics and in politics, urged the appointment of the present Royal Commission : but we all know that the Government in $1906^{\circ}$ was in the mood for Royal Commissions. I cannot find much evidence that the general public had any great desire for the Commission; but I am sure that the appointment of the Commission was very acceptable, I will even say that it was delightful, to all who were either engaged in the making of these experiments, or in upholding the value and the necessity of them.

For here, at last, was a grand opportunity to tell the public all about them. For thirty years the antivivisection societies had been flooding the country with tons of pamphlets, leaflets, lectures; petitions, appeals, letters, advertisements, and books. It is true that they had not made any practical difference to the work that had to be done; still, it was time that the country should be possessed of a clear, full, exhaustive statement, made by men of authority in the presence of men of authority, concerning all experiments on animals in this country under the restrictions of the Act. In 1875 the evidence before the Royal Commission had mostly been technical, abstruse, occu. pied mainly with physiology, and hardly intelligible to the general reader. In 1906, the whole world was interested in bacteriology; public imagination had been caught and fired by the work of Pasteur and of Lister and of Koch. The discovery of diphtheria antitoxin and of thyroid extract, the mapping out of the motor areas of the brain, the protection of sheep and cattle against epidemic diseases, appealed to everybody. Then, above all, came the news, what was being done in tropical medicine. Men 
were taking their lives in their hands, and some of them had lost their lives, in India, on the Gold Coast, or in the Uganda Protectorate. Expedition after expedition was going out from Liverpool, more romantic than any adventurer in the days of Elizabeth, and infinitely more beneficent. How they fought the plague in India, how they stamped out the yellow fever in Havana, the malaria wherever the malaria was, and what they did for Texas cattle fever, and for the tsetse-fly disease-all these mighty works were read and believed, just as we read and believe the story of Agincourt or Lucknow. In brief, the works of science had come down at last, out of the laboratories, into the national life and the national conscience; and every man of science who had watched these wonders in the making, or had something to do with the making of them, said, "Now at last this country is beginning to understand what it owes to experiments on animals. And we will use this Royal Commission for the education of the public; they shall have chapter and verse for everything; they shall have, for the first time in their lives, a careful and complete history of the Thirty Years' War against disease." In brief, the men of science welcomed the present Commission with gladness, because it was so exactly the very thing that they wanted.

They had so much to tell the Commission, so many things that they wished to get into the public mind, that they had to be very careful to avoid the overlapping of evidence, and all waste of precious time. So, on the appointment of the Commission, a meeting was held of representatives of some sixty or seventy scientific or medical societies; and from these representatives a small executive committee was formed, with Professor Starling as chairman. It was the business of this committee to divide the whole history of modern experiments on animals, giving each witness a part of it; to be in recognized correspondence with the Royal Commission; and to watch and record the whole course of the inquiry. We owe it to Professor Starling's committee that the public possesses, in five large Blue Books, a most admirable history of all experimental medicine in this country, back to the days of the 1875 Commission. Then, when the present Commission, having sat from October, 1906, to March, 1908, and heard no less than 21,761 questions and answers, decided that they did not desire any further evidence, it seemed a pity that Professor Starling's com. mittee should come to an end. There was need, so it seemed, for some association or society which should permanently remind the public of these facts about experiments on animals, and should steadily oppose the antivivisection societies. Such a society might, it seemed, do good work without interfering in any way with the work of the Association for the Advancement of Medicine by Research. That association is privileged to advise the Home Office, and by virtue of that privilege is not a public or militant body. Therefore, at a meeting of Professor Starling's committee in January of the present year, the Research Defence Society was founded. It began with seven members, which was a lucky number. It has now, October 8th, 1,472 members, of whom 156 are ladies. All societies, I suppose, are much the same in the way in which they set to work to succeed in life; they all send out notices and have meetings and make rules, and so forth; but I think the success of the Research Defence Society has one or two points of special interest.

For one thing, it has accepted, for better for worse, the fact that everybody talks about disease, and the treatment of disease, not only in conversation, but in every newspaper in the land. Against this universal talk, it is the tradition of our profession that we doctors should not talk mucin about disease, even at a dinner party, and still less in a newspaper. Yet, surely, it may be right that we should have a society for that purpose. Thus, in America, the American Medical Association has created a Board of Public Instruction on Medical Subjects, which we cannot doubt must have its hands full of work; and, in our own country, we have such bodies as the Jenner Society, and other societies which publish and distribute practical advice in the interests of the national health. For this reason, the Research Defence Society has issued, among its pamphlets, an account of the value of antitoxin in the treatment of diphthevia. When we remomber that the antivivisectionists call this entitoxin "animal filth," and oven digtribute tracts - warning you against it, thrusting them on people in the public streets, we shall all be agreed that we ought to do something for the sake of the children. But, of course, that is but a part of the work of the Research Defence Society. It is, first and foremost, a society for telling the truth about a very important set of facts which have been simply saturated with falsehood. As there is in the Roman Church a Catholic Truth Society, so now we have got a Scientific Truth Society; and that is why the Research Defence Society has had such a good welcome. People do love a society that offers them, in return for their subscriptions, nothing but a new idea. Especially, I think, they love an unpopular cause. They love the righting of a wrong, the wiping out of an insult, and a stand-up fight against prejudice and hatred. All through the innumerable letters which have come to me as Honorary Secretary of the Research Defence Society there is this pleasant sense, that peuple are really thankful for the existence of a society created for one purpose alone-to tell the truth, and shame the antivivisection societies.

There are sixteen or seventeen of these societies in this kingdom. It would take a fool of no ordinary dimensions, to make light of our national love for animals, our universal wish that they should be protected from all pain, and even from all discomfort, save in the service of man. Every one of us believes that such general consideration and kindly feeling toward animals to-day are of immeasurable value to the spiritual health of the nation. But none the less, or all the more, we have the right to ask all, who oppose experiments on animals, to accept the truth about the work that is done in their own country, and at the present time, under the restrictions of the Act. And I think we have this further rightto ask them, till they have done that, till they have patiently and fairly and thoughtfully heard what our men of science and the honoured leaders of our profession have to tell them as to the value and the necessity of experiments on animals, not to give either their names or their approval or their money to these antivivisection societies, which have now for thirty years been fighting so hard, not only against science. but among themselves, and have received about $£ 80,000$ and have accomplished next to nothing. If they had all of them been Research Defence Societies instead of what they are, the line on my chart of each year's work from 1875 onward would have been no other than what it is; and in their vain attempt to stop. all experiments on animals these many societies have deluged this unhappy country with lectures and with literature which, happily for us, have quite a place of their own in the long history of bad lectures and bad literature.

Against these societies we now have a society which may truly be called representative of the collective good feeling, philanthropy, scientific mind, and passionate respect for plain facts, which are no less admirable than our care for animals, and are even more necessary for the health and the strength of the national conscience. Thus at last we come to the work of the Research Defence Society. Its work is not only to defend the practice of research, but to defend the honour of research. Our men of science have been grossly and most impudently insulted, and we are not going to stand that any longer. The British public is sick to death of hearing Pasteur called a torturer, and Lister called a fool ; sick to death of the "platform facts," the placards, the public meetings, of these antivivisection societies.

The work of the Research Defence Society, therefore, is mostly, if I may dare to use the word, apostolic. It is willing, always, to send a representative to any straightforward debate, and even to meet at such a debate the representative of an antivivisection society. Only, it draws the line, very properly, at accepting challenges from antivivisection societies, or arranging debates with them. It is also willing to arrange with any literary society or institute for the giving of a lecture or address, which would be open to fair discussion. But its more immediate daily business: is the sending to all applicants of the pamphlets and leaflets which it has already issued.

Bound copies of these pamphlets and leaflets rave lately been sent to all the chief public or educational libraries in the kingdom. But, of course, it is nothing to send a book to a public library in a place like Manchester or Bournemouth. What is everything is a branch seciety 
in every great town in England, spreading in that town a more general knowledge of the facts about experiments on animals. Finally, as it is the privilege of a new society to bo ambitious, and to look far afield for the extension of its work, so the Research Defence Society has been in communication with some of the most eminent American physicians and surgeons, and steps have now been taken to the formation of a Research Defence Society in the United States.

I need not say that I shall be truly glad now, or at any time, to be of service either to you, Gentlemen, or to any of your acquaintance who may care to have the Society's literature, or to be informed on this or that particular point. It was a happy thought in the mind of Professor Starling's committee to found a society which should bring together, in the unity of science and in the cause of truth, so great a body of educated Englishmen and Englishwomen. The name of Lord Cromer, its President, and the long list of the names of its Vice-Presidents, tell what the world really thinks of the science and art of our profession. Of course, the society has not done growing ; it is only eight months old; it will have many more members by-and-by. It will never cease to be welcome till the antivivisection societies cease to be able to obtain a bearing. Doubtless, its work will be advanced by the final report of the Royal Commission, which may soon be published; meanwhile it looks back thankfully to the good reception which has been given to it, and to the good work that it has already done.

\section{THE LIMITATIONS OF A PURIN-FREE DIET.*} By ALEXANDER BRYCE, M.D., D.P.H.CAMB., BIRMINGHAMT.

THE advantages to be derived from the adoption of a purin-free diet are sometimes so notable that there is a tendency on the part of an enthusiast to look upon it as a ipanacea for all the ills that flesh is heir to. Quite recently the evidence in favour of such a diet has been accumulat ing, and amongst a certain section of the profession it is taken for granted that the fallacies which have been exposed time and again no longer hold any weight, and that the uric acid theory, so called, has been proved to a demonstration. The arguments from the theoretical point of view in favour of such a diet are so plausible and so difficult to refute that one is apt lightly to adrocate its adoption - without considering the consequences. For some years now I have been much attracted by its possibilities in the treatment of disease, and in selected cases where the ordinary therapeutic methods had failed, I have had no hesitation in encouraging patients to give it a thorough trial. It is astonishing what a fascination such a theory has for the young and enthusiastic physician in the first flush of his disappointment with both old well-worn remedies and new much vaunted specifics. On the face of it the whole thing seems so absurdly simple that it does not need any elaborate demonstration to prove its truth. The body of your ailing patient is a more or less intricate filter into which for purposes of nutrition have been poured certain solutions of nutriment containing certain poisons which are not completely excreted, and hence accumulate therein, producing well-defined acute or chronic diseases according to the temperament of the patient. To eliminate the disease all that seems necessary is to expunge the poison from the food, and, where this cannot be done, to select foods which contain no poison, and you go forward with the simple and at first not easily shaken faith that disease in such circumstances is really an impossibility.

Even when, after much patient research-as I have undertaken-you prove without the shadow of a doubt that the bulk of the purins and xanthins ingested are as a rule easily excreted within forty-eight hours, you do not lose faith, and you look round upon the countless examples of healthy men and women who have lived to a good old age and have triumphed over all the dangers of the foods against which Haig issues his diatribes as having become in some unaccountable way possessed of the true elixir vitae. After a few years' careful observa'*A paper read before the Birmingham Branch of the British Medical
Association. tion, however, you are not quite so sanguine as to the universal cure-all, and I propose in this short paper to give a record of some cases in which the results have not. been so favourable as some recently reported.

Group I.-Headaches.

This group comprises headaches of a periodical nature, sometimes accompanied by sickness, at other times not, but always of the character so generally ascribed to the condition known as uric-acidaemia. All of these cases occurred in ladies who refused to adopt a rigorous purinfree diet, but as a compromise agreed to give up tea, coffee, and cocoa. In the six cases $I$ have noted the results were remarkable, as, after a preliminary exacerbation of the headache, it disappeared never to return. The following is a typical case:

Mrs. J., aged 38, engaged in much religious work, involving, doubtless, the drinking of much tea, suffered from severe head aches of the migraine type, compelling confinement to the hous for the whole day. For a week after the exclusion of tea from her dietary she had a severe and continuous headache, and thereafter complete freedom. After abstaining from tea for eighteen months she again, about four years ago, began to take it in smaller quantities, much diluted with water, without a it in smaller quantitie
return of the headache.

I am of opinion that the great majority of such head: aches in women are due to caffeine poisoning, and for a long time are kept at bay by an extra dose of the poison, so that it becomes quite a common thing for the sufferer to fly to another cup of tea in order to obtain relief, with disastrous results in the long run.

Tea, coffee, and cocoa are nerve poisons, cardiac poisons, and cerebral excitants, and the headache is sufficiently explained by the toxic factor, without having recourse to the statement that xanthins are analogous to purins, and hence are converted into uric acid, or one of its congeners, and as such accumulate in the body. Whenever the dose of the poison is reduced to the amount the body can tolerate the bad effects cease. Probably the temporary relief obtained by a cup of tea is due to the fact that caffeine quickly acts as a diuretic, and leads to an increased excretion of the nitrogenous elements, especially of urea and the fatigue products generally. This is only possible with moderate doses, because it has been experimentally demonstrated that the greater the quantity of caffeine absorbed the less in proportion is it metabolized, and hence the total urinary purin is proportionately diminished. This cumulative action sufficiently explains the toxic effect of large quantities of tea and coffee.

\section{Group II.-Epilepsy.}

In this malady, in my experience, a purin-free dietary offers the best chance of a cure, and two of my cases after years of suffering have quite got rid of their attacks. In neither case, however, was the diet absolutely purin free although the rules laid down by Haig otherwise were carefully followed-namely, (1) that a minimum of fluid be taken, (2) that the bowells be kept extremely well open; and $I$ added a third instruction, to avoid all salt in the food, replacing it in the bread used by a small quantity of sodium bromide. A third case :

Miss S., aged 24, has now been under treatment for four years without having had a single attack, as compared with one every three months before that; the only purin-containing food allowed is $6 \mathrm{oz}$. of some kind of animal food once daily.

This case, as well as the three I am about to mention, have had each day for the first two years of their treatment 10 minims of tincture of digitalis and 20 grains of sodium bromide. These three cases, on a limited purinfree diet, had not a single bad symptom during their course of treatment, differing markedly from the next three, on a purin-free diet.

1. Mrs. S., aged 37, had attacks of epilepsy every month for several years. Seven years ago I put her on an entirely purinfree diet, with rapid improvement. After the first six months of less frequent and less severe attacks, she had a long spell in which no attack occurred, although she was much afflicted with muscular rheumatism, and at the end of three years had a sharp attack of pneumonia. For a long time after her recovery she complained bitterly of muscular rheumatism, and was she complained bitterly of muscular rheumatism, and was extremely weak and always tired. After this time the epilepsy
began gradually to return, and now attacks occur about once in three months. The patient is, however, satisfied, and adheres to the diet, as she says she is not so ill after the attacks as when on a mixed diet, and, indeed, she and her husband and family have become fond of the rigorous diet. 